stručni članak

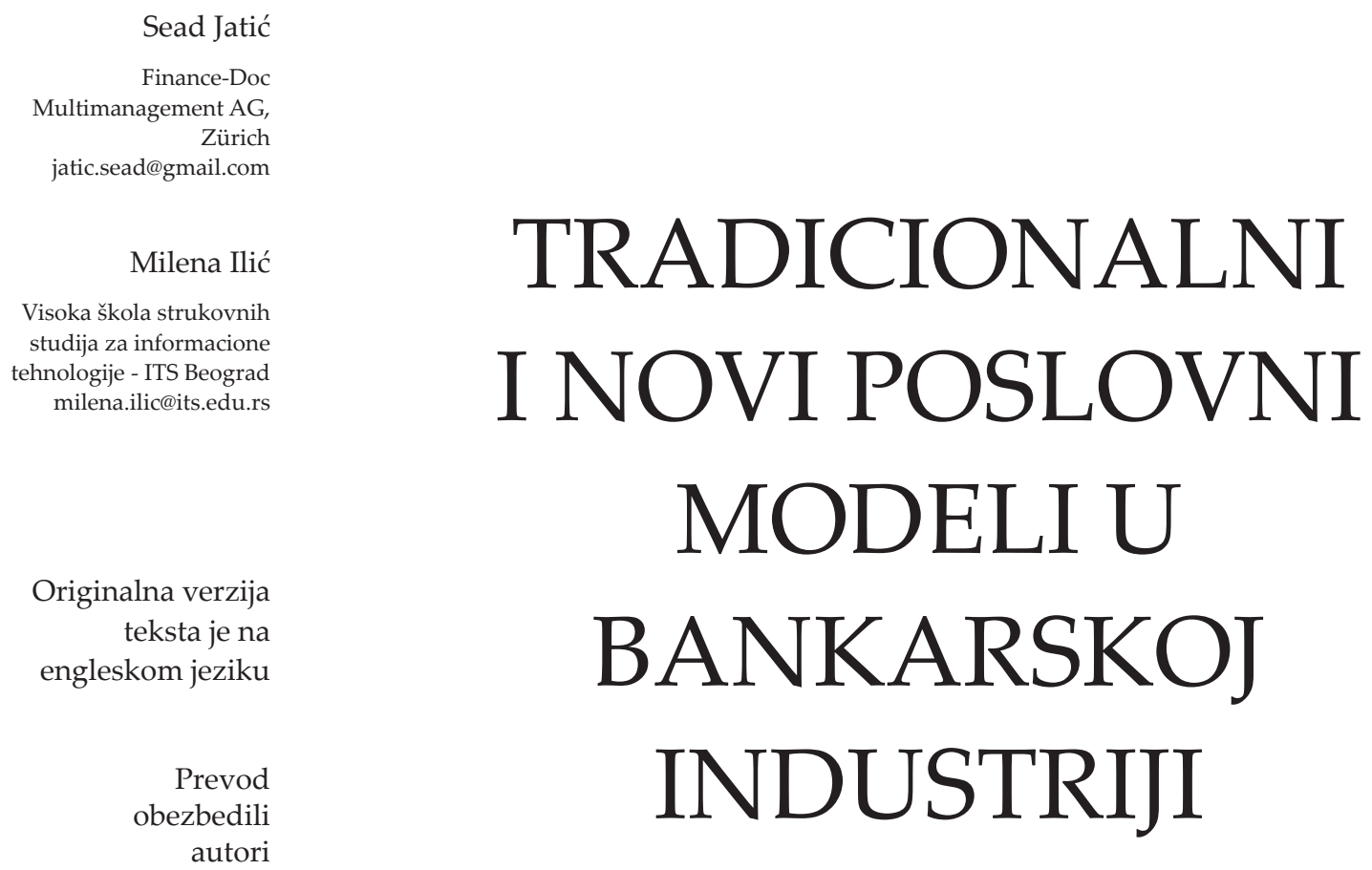

\title{
Rezime
}

Poslovanje današnjih finansijskih tržišta se ne može zamisliti bez postojanja banaka, kao osnovnih posrednika u obavljanju velikog broja finansijskih aktivnosti. Odnosi koje banke uspostavljaju sa svojim klijentima zasnivaju se na razmeni finansijskih sredstava i informacija, najčešće na duži vremenski rok, radi ostvarivanja brojnih zajedničkih ciljeva. Tokom prethodnih decenija banke su napredovale, usavršavale svoje poslovanje, kako bi bile u mogućnosti da svojim klijentima ponude vrhunske usluge. Veliki deo njihovog poslovanja zasnovan je na inovacijama, ali i specifičnim strategijama koje su se pokazale kao manje ili više uspešne.

Poslovni modeli koji se primenjuju u bankarskom poslovanju su raznovrsni, a njihovim kontinuiranim inoviranjem banke nastoje da obezbede značajniju konkurentsku prednost na tržištu. Poslednjih godina primetna je izražena konkurencija na svetskom bankarskom tržištu i neprekidna potraga banaka za poslovnim modelima koji mogu da im obezbede poslovni uspeh na dug rok. Inovacije se implementiraju u svim segmentima bankarskog poslovanja, a razvoj modela i strategija prioritet je svih nivoa menadžmenta u današnjim bankama.

Ključne reči: poslovni modeli, banke, finansijska tržišta, strategije

JEL: F60, G21, M20, O30 


\section{TRADITIONAL AND} NEW BUSINESS

Milena Ilić

Information Technology School - ITS Belgrade milena.ilic@its.edu.rs

\section{MODELS IN THE}

The original version of the text is in English

Translation provided by the authors

\section{Summary}

The management of today's financial markets would be impossible without banks as the prime mediators in performing a large number of financial activities. The relationship established between banks and their clients is based on the exchange of financial resources and information, often in the long run, in order to achieve numerous common goals. Over the past few decades, banks have advanced and improved their management in order to offer their clients top services. A large part of their business is founded upon innovations as well as specific strategies that have proven to be more or less successful.

The business models that are applied in bank management are various, and by continuous innovation in this field banks strive to secure a significant competitive advantage in the market. Recent years have seen the strong competition in the global market and continuous seeking for the business models that could secure long-term business success to the banks. Innovations have been implemented in every segment of the banking business, and development of business models and strategies is the priority at every level of management in today's banks.

Keywords: business models, banks, financial markets, strategies

JEL: F60, G21, M20, O30 


\section{Uvod}

Globalizacija je značajno uticala na promenu tradicionalnih odnosa između učesnika na tržištu (Teece, 2010). U takvim uslovima poslovanja, traganje za novim poslovnim modelima postaje neminovnost. Najvažniji izazov modernog poslovnog modela jeste da razvojem inovacija prevaziđe tradicionalnu, čvrstu industrijsku logiku (Gassmann, Frankenberger \& Csik, 2014). Kreiranje poslovnog modela danas je krucijalna odluka menadžmenta kompanija, koje žele stabilnu budućnost i poslovni uspeh (Zott \& Amit, 2010).

U radu će se razmatrati nekoliko poslovnih modela i strategija, za koje verujem da će biti vrlo korisne u budućnosti mnogih kompanija. Plavi okean (Blue Ocean) je poslovni model kojim se može obezbediti visoko profitabilan rast (Chan Kim \& Mauborgne, 2005), pri čemu se tradicionalni koncept konkurentske prednosti menja u vrednost inovacije kao primarni cilj kompanija koje streme neiskorišćenim delovima tržišta (Burke, Van Stel \& Thurik, 2009).

Otvorene inovacije (eng. Open Innovation) su koncept koji se odnosi na korišćenje internog i eksternog znanja, a kroz odnos priliva i odliva znanja najbolje se mogu unaprediti inovacije $u$ kompaniji (Cheng \& Huizingh, 2014).

Model "otvorene inovacije" je praktičan alat, koji zahteva nove strategije i odluke za eksploataciju inovativnih aktivnosti u poslovanju (Aranha, Prado Garcia \& Correa, 2015). Pored toga, i "big data" koncept nalazi svoju primenu u poslovanju današnjih kompanija, jer su sve kompanije danas fokusirane na implementaciju tehnika za obradu velikih količina podataka, od kojih se mogu ostvariti značajne koristi (Bughin, 2016).

I na kraju, jedan od najvažnijih procesa u kompanijama današnjice jeste i digitalizacija, koja se zasniva na primeni savremene tehnologije, koja može unaprediti svaki aspekt poslovanja (Forest \& Rose, 2015). Digitalizacija u bankama ima fundamentalan uticaj na strukture i procese $u$ ovim finansijskim institucijama (Korner \& Zimmermann, 2000), o čemu će više biti reči u nastavku rada.

\section{Tradicionalni poslovni modeli u bankarskoj industriji}

Bankarska industrija jedna je od najrazvijenijih industrija sveta, imajući u vidu širok spektar usluga koje danas može da ponudi svojim klijentima i ostalim korisnicima njenih usluga. Ekspanzija bankarskog poslovanja dešava se u poslednjim decenijama, kada je postalo jasno da često fizička ili pravna lica nisu u mogućnosti da finansiraju svoje potrebe iz redovnih prihoda koje ostvaruju, pa im je potrebna pomoć ove finansijske institucije $u$ prevazilaženju prepreka koje mogu postojati između potrošnje i prihoda. Pored toga, banke danas obavljaju čitav niz usluga, koje nisu a priori usko vezane za njihovu delatnost, ali omogućavaju bankama da svojim klijentima ponude kompletan asortiman finansijskih usluga koje su im potrebne.

Kada je reč o izboru poslovnog modela, svaka banka nastoji da se što više razlikuje od ostalih banaka na tržištu, koje su joj konurenti, kako bi klijenti bili u mogućnosti da prepoznaju dodatnu vrednost koju konkretna banka nudi u poređenju sa ostalima. Da bi svoje poslovanje uklopile u postojeće definicane ciljeve, banke teže da se uključe u različite strateške aktivnosti posredovanja i da izaberu specifičnu bilansnu strukturu svog poslovanja. Iz navedenih razloga, izbor poslovnog modela banke vođen je težnjom da se iskoriste sve njene postojeće prednosti i unapredi usluga koja se nudi bankarskim korisnicima (Roengpitya, Tarashev, Tsatsaronis, 2014).

Preispitivanje bankarskih poslovnih modela treba da postane regularna aktivnost svake savremene banke, a posebno na tu činjenicu ukazala je svetska ekonomska kriza s kraja prve decenije XXI veka. Mnoge banke su tada bile ugrožene, neke čak prestale sa radom, a sve sprovedene reforme $\mathrm{u}$ domenu bankarskih propisa, pre svega u vezi sa implementacijom Basel III koncepta, ukazale su na podsticaje da je neophodno da mnoge banke preispitaju svoje poslovne modele, sa ciljem unapređenja poslovnih performansi i samim tim poslovnog uspeha svake današnje banke (Mergaerts, Vander, Vennet, 2016).

Grupa autora (Roengpitya, Tarashev, Tsatsaronis, 2014) je definisala tri osnovne 


\section{Introduction}

Globalization has significantly influenced the shift in the traditional relationship among the participants in the market (Teece, 2010). In such business conditions, the search for business models becomes a necessity. The biggest challenge of a modern business model is to overcome the stiff traditional industrial logic through innovation development (Gassmann, Frankenberger \& Csik, 2014). The creation of business models is nowadays a crucial management decision for the companies that strive for a stable future and business success (Zott \& Amit, 2010).

This paper considers several business models and strategies that shall become vital for the future of many companies. The Blue Ocean Strategy is a business model that could ensure an intensely profitable growth (Chan Kim \& Mauborgne, 2005), while the traditional concept of competitive advantage changes into the innovation value as a primary goal of the companies that aim to win the untapped market (Burke, Van Stel \& Thurik, 2009).

Open innovation is a concept that refers to the usage of internal and external knowledge, and the relation of knowledge inflows and outflows is the best way to advance innovations in a company (Cheng \& Huizingh, 2014).

The Open Innovation Model is a practical tool that requires new strategies and decisions for the exploitation of innovative activities in management (Aranha, Prado Garcia \& Correa, 2015). Furthermore, the Big Data concept is used in modern companies' management, because nowadays all companies are focused on the implementation of techniques for processing a large amount of data that could be highly useful (Bughin, 2016).

Finally, one of the most important processes of today's companies is digitalization which is established upon the application of modern technologies and which could boost every aspect of management (Forest \& Rose, 2015). Digitalization in banks has a fundamental impact on the structures and processes in these financial institutions (Korner \& Zimmermann, 2000), and is explained in detail in the third chapter of this research paper.

\section{Typical Business Models in the Banking Industry}

The banking industry is one of the most developed industries in the world, bearing in mind a wide spectrum of services it can nowadays offer to its clients and other users of its services. Banking has been expanding over the past few decades, and it became clear that natural persons and legal entities are often unable to support all their needs with their regular income. Hence, they need some help from the financial institutions in order to overcome the obstacles that might exist between income and consumption. Furthermore, banks today provide a series of services that are not a priori closely related to their field but enable them to offer their clients a complete range of financial services they might need.

When it comes to the business model selection, every bank strives to distinguish itself as much as possible from the other banks on the market, i.e. from its competition, in order to help its clients recognize that it offers an additional value in comparison to others. In order to adjust their management to the existing defined objectives, banks aim to engage in different strategical intermediation activities and to select a specific balance sheet structure for their business. Therefore, the bank business model selection is driven by the pursuit to employ all its present advantages and to improve the services that are offered to bank users (Roengpitya, Tarashev, Tsatsaronis, 2014).

Reexamination of the bank business models should become a regular activity for every modern bank, which was clearly pointed out during the global economic crisis in the late 2000s. Many banks were jeopardized then, some even stopped working, and all of the implemented reforms in the domain of banking regulations, primarily those related to the implementation of the Basel III framework, indicated that it is necessary for many banks to review their business models in pursuance of business performance advancement and thus the business success of every contemporary bank (Mergaerts, Vander, Vennet, 2016).

A group of authors (Roengpitya, Tarashev, and Tsatsaronis, 2014) defined three basic categories of business models in the 
kategorije poslovnih modela u današnjem bankarskom sektoru:

- Komercijalna banka koja je finansirana iz maloprodaje (maloprodajom)

- Komercijalna banka koja je finansirana iz veleprodaje (veleprodajom)

- Banka koja je orijentisana ka tržištu kapitala. Prve dve navedene kategorije poslovnih modela u bankama se razlikuju prvenstveno po kombinaciji načina finansiranja (da li je u pitanju finansiranje na malo ili na veliko), dok treći poslovni model ukazuje na činjenicu da je banka prvenstveno angažovana $u$ oblasti trgovačkih aktivnosti. Sigurno se u praksi mogu identifikovati varijacije navedenih modela, gde su moguća određena odstupanja, ali ovo generalno grupisanje poslovnih modela omogućava lakše sagledavanje organizacije poslovanja banke i utvrđivanje njenih osnovnih poslovnih ciljeva.

Sve navedeno ukazuje na činjenicu da poslovni modeli $\mathrm{u}$ poslovanju savremenih banaka zahtevaju značajne promene, kako bi se prilagodili trenutnoj situaciji na tržištu. Brojne reforme koje se poslednjih godina dešavaju u bankarskom sektoru podstrek su i promenama u okviru samih banaka, kako bi pronašle pravu formulu za nastup na tržištu i ostvarivanje konkurentske prednosti na dug rok.

\section{Novi poslovni modeli za banke}

Sve promene koje su se dogodile od početka XXI veka zahtevaju drugačiji, novi pristup poslovanju savremenih kompanija, između ostalog i poslovanju današnjih banaka. Poslednja ekonomska kriza pokazala je da nijedna banka kreiranje inovativnih poslovnih modela $u$ bankarskom poslovanju i mogu dati smernice bankama za dalje uspešno poslovanje.

\section{Strategija plavog okeana}

Koncept modela strategije plavog okeana (tzv. Blue Ocean Strategy) polazi od pretpostavke da se savremeno globalno tržište može posmatrati kao univerzum kreiran od dva tipa okeana: crveni i plavi. Crveni okean obuhvata sve one industrije koje su danas poznate i postojeće, dok plavi okean simbolizuje industrije nepoznatog tržišnog prostora. Za crveni okean karakteristično je poznato okruženje, jasno definisane granice između industrija, postoje pravila konkurentnosti, a osnovni cilj kompanija jeste da osvoje što veći deo postojeće tražnje. S druge strane, plavi okean ukazuje na neiskorišćene tržišne kapacitete, na stvaranje tražnje a ne njeno pridobijanje, pri čemu se mogu stvoriti značajne mogućnosti poslovnog rasta. U okviru ove strategije očekuje se prevazilaženje postojećih granica industrije, a konkurencija nije jasno definisana, još uvek ne postoje koncizna pravila igre u ovom poslovnom modelu. Analogija sa okeanom, kao velikim, nepreglednim prostorom, treba da ukaže na činjenicu da još uvek postoji neistražen prostor u pogledu tržišnog potencijala, koji može biti izvor poslovnog uspeha za kompanije koje ga prepoznaju (Chan, Mauborgne, 2005).

Za razliku od konvencionalnih strategija, impelementacija strategije plavog okeana može da obezbedi ključni izvor poslovnog rasta kompanije, na osnovu promena i inovacija, a ne stabilnosti konvencionalnih strategija (Lindič, Bavdaž, Kovacič, 2012). ne može biti potpuno sigurna u poslovni model koji primenjuje, pa se javila potreba inoviranja postojećih poslovnih modela, kako bi se banke pripremile za sve potencijalne rizike koji se mogu $u$ poslovanju dogoditi. U nastavku rada biće objašnjene neke od osnovnih poslovnih strategija i modela, koje mogu biti korisne za
Tabela 1: Razlika između strategije crvenog okeana i strategije plavog okeana

\begin{tabular}{|l|l|}
\hline Strategija crvenog okeana & Strategija plavog okeana \\
\hline $\begin{array}{l}\text { Poslovanje se obavlja u postojećim } \\
\text { tržištima }\end{array}$ & $\begin{array}{l}\text { Ideja je da se kreira novi tržišni } \\
\text { prostor koji je bez konkurencije }\end{array}$ \\
\hline $\begin{array}{l}\text { Fokus je orijentisan ka pobeđivanju } \\
\text { konkurenata }\end{array}$ & Konkurencija nije relevantna \\
\hline Koristi se postojeća tražnja & Stvara se nova tražnja \\
\hline $\begin{array}{l}\text { Trade-off između vrednosti i } \\
\text { troškova je relevantan }\end{array}$ & $\begin{array}{l}\text { Trade-off između vrednosti i } \\
\text { troškova nije relevantan }\end{array}$ \\
\hline $\begin{array}{l}\text { Ceo sistem kompanijiskih } \\
\text { aktivnosti se fokusira na strateške } \\
\text { izbore diferencijacije proizvoda ili } \\
\text { niskih troškova }\end{array}$ & $\begin{array}{l}\text { Ceo sistem kompanijiskih aktivnosti } \\
\text { se fokusira na strateške izbore } \\
\text { diferencijacije proizvoda i niske } \\
\text { troškove }\end{array}$ \\
\hline
\end{tabular}


contemporary banking sector:

- Retail-funded commercial bank;

- Wholesale-funded commercial bank;

- Capital markets-oriented bank.

The first two categories of bank business models differ primarily in terms of the funding mix (whether we are dealing with retail or wholesale funding), while the third business model indicates the fact that the bank is primarily engaged in the field of trading activities. Variations of the stated models can certainly be identified in practice, but this basic categorization of business models facilitates the comprehension of bank management organization and establishing its basic business goals.

All of the above leads to the fact that the business models in today's bank management require significant changes in order to adapt to the current situation in the market. Numerous reforms that have been occurring in the banking sector recently are encouraging the changes in the banks themselves so that they could find the right formula to present themselves on the market and achieve a long-term competitive advantage.

\section{New Business Models for Banks}

All changes that have happened since the beginning of the $21^{\text {st }}$ century require a new, different approach to the management of modern companies and thus to the management of modern banks. The last economic crisis has shown that no bank can entirely rely on its business model, so the need for innovation in business models occurred in order to prepare the banks for new risks that might occur in their management. In the ensuing sections we will elaborate on some basic business strategies and models which can be useful in creating new innovative business models in bank management, thereby giving the banks some guidance for successful management in the future.

\section{Blue Ocean Strategy}

The concept of the Blue Ocean Strategy starts with the assumption that the contemporary global market can be perceived as a universe that consists of two types of oceans: red and blue. The Red Ocean consists of all industries that are known and in existence today, while the Blue Ocean symbolizes the industries of the unknown market space. The Red Ocean is characterized by the familiar environment, the clearly defined boundaries between industries, the existence of competitiveness rules, while the primary goal of the companies is to grab the largest share of the existing demand they can. On the other hand, the Blue Ocean points to the unused market capacities, the demand creation rather than its conquest, all in order to generate significant possibilities for business growth. It is expected to cross the existing boundaries of the industry within this strategy, and the competition is not clearly defined nor are there any concise rules of the game in this business model. The analogy of the ocean, a vast chaotic space, should suggest the fact that there will always be an unexplored space when it comes to the market potential which could be the source of business success for the companies which recognize it (Chan, Mauborgne, 2005).

Unlike the conventional strategies, the implementation of the Blue Ocean Strategy can provide a key source for a company's business growth through changes and innovation rather than through the stability of the conventional strategies (Lindič, Bavdaž, Kovacič, 2012).
Table 1: Differences between the Red Ocean and Blue Ocean Strategy

\begin{tabular}{|l|l|}
\hline The Red Ocean Strategy & The Blue Ocean Strategy \\
\hline $\begin{array}{l}\text { Business is done in the existing } \\
\text { market space }\end{array}$ & $\begin{array}{l}\text { The idea is to create a new, } \\
\text { uncontested market space }\end{array}$ \\
\hline Focus is on beating the competition & Competition is totally irrelevant \\
\hline Using the existing demand & Creating the new demand \\
\hline Value-cost trade-off is important & $\begin{array}{l}\text { Value-cost trade-off is not so } \\
\text { relevant }\end{array}$ \\
\hline $\begin{array}{l}\text { The whole system of company } \\
\text { activities focused on the strategic } \\
\text { choice between products } \\
\text { differentiation or low cost }\end{array}$ & $\begin{array}{l}\text { The whole system of company } \\
\text { activities aimed at the pursuit } \\
\text { of products differentiation and } \\
\text { low cost }\end{array}$ \\
\hline
\end{tabular}


Banke koje deluju u crvenom okeanu su tradicionalne banke koje nisu u potpunosti prihvatile mogućnosti koje nude moderne tehnologije ili u ovom slučaju mogućnosti digitalne poslovne transformacije. Tradicionalne banke se bore s ekonomskom nestabilnošću i profitom koji je nizak ili stagnira. Bankovni propisi, koji su u mnogim zemljama vrlo strogi, takođe imaju negativan uticaj na njihovo poslovanje.

Banke koje su u "plavom okeanu" jesu upravo one banke koje odlikuje korporativno preduzetništvo i koje konstantno inoviraju i koriste inovacije iz drugih sektora kako bi unapredile svoje poslovanje. Banke koje plivaju u "plavom okeanu" su savremene, moderne, smele, lideri u bankarskom sektoru. Ove banke su prevazišle tzv. "bricks-and-mortar" model aktivnosti i usresredile se na digitalno bankarstvo.

\section{Otvorene inovacije}

Najjednostavnije rečeno, "otvorene inovacije" predstavljaju koncept koji se odnosi na implementaciju priliva i odliva znanja, kako bi se unapredile interne inovacije i proširila potencijalna tržišta za eksternu eksploataciju inovacija (Cheng, Huizingh, 2014).

$\mathrm{U}$ ranijem periodu, koncept "otvorenih inovacija" se više istraživao u oblasti proizvodnih preduzeća, a usluge su bile u tom kontekstu manje zastupljene. Međutim, današnja poslovna praksa je pokazala da se ovaj koncept uspešno može primeniti i u uslužnom sektoru privrede, radi ostvarivanja pozitivnog uticaja na poslovne rezultate, kao i radi povećanja intenziteta konkurencije (Foroughi i drugi, 2015). Zato "otvorene inovacije" kao koncept privlači sve veću pažnju današnjih stručnjaka.
Iako "otvorene inovacije" nisu sasvim novi koncept, smatra se da su najveći značaj doživele tek u poslednjoj deceniji. Kao razlog tome navodi se da se pojavila potreba za boljim upravljanjem inovacijama, a smatra se da se povećanje inovativnosti može ostvariti kako sticanjem znanja u okviru same kompanije, tako i idejama koje dolaze iz eksternih izvora, ali i odlaznim oblicima inoviranja, kako bi se eksterno potvrdila efikasnost eksploatacije inovacija (Granstrand, Holgersson, 2014). Suština koncepta "otvorene inovacije" ukazuje na mogućnosti korišćenja internih ideja kompanije i znanja iz okruženja u kome ona posluje, kako bi se razvili brojni inovativni procesi $\mathrm{i}$ unapredilo postojeće poslovanje. Kada kompanija razvije čvrst odnos sa eksternim akterima na tržištu, može da razvije brojne efikasne poslovne strategije, kojima će nastojati da maksimalno iskoristi svoje tehnološke sposobnosti, u procesu razvoja novih proizvoda i usluga u poslovanju (Vega-Jurado i drugi, 2015).

\section{Big Data}

Jedna od najznačajnijih karakteristika savremenog tržišta jeste da se informacije javljaju kao jedan od osnovnih faktora $\mathrm{u}$ organizovanju procesa poslovanja, jer ko poseduje blagovremene informacije ima moć na tržištu. U tom kontekstu često se pominje big data sintagma, koja označava kompleksne setove podataka, kod kojih nije moguće primeniti tradicionalne tehnike njihove obrade, jer su u pitanju podaci koji su brojni, raznovrsni i različitih formata. 
Banks that operate within the Red Ocean are the traditional banks that have not entirely embraced the possibilities offered by the modern technologies or in this case the possibilities of the digital business transformation. Traditional banks are struggling with the economic instability and with the profits that are low or stagnating. The banking regulations, which are in many countries quite strict, also have a negative influence on their business.

On the other hand, banks that operate within the Blue Ocean are the ones characterized by the corporative entrepreneurship and the ones that are constantly innovating and using the innovations from the other sectors to improve their management. The banks that are "swimming" in the Blue Ocean are modern and bold leaders in the banking sector. These banks have outgrown the "bricks-and-mortar" model of activities and focused on digital banking.

\section{Open Innovation}

Essentially, open innovation is a concept that refers to the implementation of knowledge inflows and outflows with a view to improving internal innovations and increasing the market potential for external exploitation of innovation (Cheng, Huizingh, 2014).

In the past, Open Innovation has been researched from the perspective of manufacturing companies, while services have been underrepresented in this context. However, today's business practice has shown that this concept can be successfully applied in the service sector in order to achieve a positive effect on business performance as well as to increase the competition intensity (Foroughi et al., 2015). For this reason, the Open Innovation concept has been attracting the increasing attention of today's experts.
Although Open Innovation is not an entirely new concept, it has gained considerable importance in the last decade. As a result, a need for better innovation management has appeared and it is believed that the increase in innovation can be achieved through gaining new knowledge in the company itself as well as through external ideas, but also through the outgoing forms of innovations that show the efficiency of exploitation of innovation (Granstrand, Holgersson, 2014). The Open Innovation concept essentially suggests the possibility to use the company's internal ideas and the knowledge from its working environment to develop numerous innovative processes and advance its management. When a company develops a solid relationship with external stakeholders, it can develop many efficient business strategies in order to fully exploit its technological abilities in the process of product and service development (VegaJurado et al., 2015).

\section{Big Data}

One of the most important characteristics of the today's market is the fact that information is the key factor in the process of business management since those who have the latest information have a powerful influence in the market. In relation to this, the "Big Data" concept is often mentioned. This term signifies a complex set of data which is impossible to process by means of the traditional processing techniques due to the fact that the data are extensive, diverse and of different format. 
Iz navedenih razloga, kompanije nastoje da razviju nove načine obrade ovih podataka, pre svega kroz upotrebu savremene tehnologije: (Bholat, 2015)

- U pitanju su podaci ogromnog obima, jer se vrlo često prikupljaju granularno (na osnovu pojedinačnog klijenta, usluge, i slično);

- Podatke karakteriše velika brzina, imajući u vidu često prikupljanje, obradu, analiziranje, ažuriranje i obnavljanje podataka;

- Podaci se kvalitativno razlikuju, što dodatno otežava njihovu obradu, ali postoji čitav set raznovrsnih tipova podataka koji mogu biti vrlo korisni za analizu.

Big data koncept dobija na značaju poslednjih godina, a na osnovu iskustva kompanija koje su ga primenile u svom poslovanju i ostvarile značajne beneficije po osnovu velikog obima podataka i naprednih tehnika za njihovu analizu. Ono što bi trebalo naglasiti jeste da postoji značajan vremenski okvir u kome se očekuju koristi od primene big data koncepta, jer rezultati neće biti vidljivi odmah, već nakon nekog izvesnog vremena, s obzirom da svaka kompanija mora da obavi odgovarajuće pripreme za njegovu implementaciju (Bughin, 2016).

Kada je reč o poslovanju banaka, u pitanju je sektor privrede koji je vrlo neizvestan poslednjih godina, a na šta je posebno ukazala poslednja ekonomska kriza. Bankarsko poslovanje može imati velikih koristi od big data koncepta, ukoliko se on u njihovom poslovanju primeni na adekvatan način. Smatra se da će veliki podaci biti budućnost poslovanja svih subjekata na finansijskom tržištu, između ostalog i banaka.

\section{Digitalizacija}

Digitalizacija je svojevrstan proces o kome se poslednjih godina sve više priča u stručnim krugovima. Upotreba savremene tehnologije u poslovanju bilo koje kompanije nije novost, ali činjenica da se ona može iskoristiti za unapređenje poslovanja na način da se potpuno automatizuje i digitalizuje privlači veliku pažnju kompanija. Digitalizacija se u novije vreme sve više dovodi u vezu sa bankarskom industrijom, gde se na pojedinim primerima svetskih banaka pokazalo da može imati značajnog efekta na poslovne rezultate ovih finansijskih institucija. Forest i Rose (Forest, Rose, 2015) u svom istraživanju ističu da je digitalizacija trend, nastao kao posledica delovanja tri značajna faktora:

- Iskustvo potrošača - težnja ka ostvarivanju većeg stepena satisfakcije kupaca ubrzala je proces digitalizacije. Kupci svoje odluke u kupovini i potrošnji donose na osnovu toga u kojoj kompanije zadovoljavaju njihove potrebe;

- Razvoj tehnologije - razvoj digitalne infrastrukture omogućio je milionima korisnika širom sveta pristup tehnologiji koja značajno može da unapredi svakodnevne aktivnosti;

- Ekonomske koristi - digitalizacija ubrzava razvoj ekonomije, otvaranje novih radnih mesta, uštede $u$ troškovima, veće obime prihoda, i slično. Obrada informacija je ubrzana, njihov kvalitet poboljšan, a vreme obrade značajno smanjeno.

Radi korišćenja svih koristi digitalizacije kompanije moraju razviti efikasnu strategiju koja treba da omogući efektivnu digitalizaciju celokupnog poslovanja. (Ristić, Anđelić, Ilić, 2017)

U zemljama koje su u razvoju, digitalizacija bankarskog sektora je ideal kom teže banke. Za razvijene zemlje, više nije u pitanju budućnost, već sadašnjost koja diktira preduslove opstanka ovih banaka na visokokonkurentnim bankarskim odnosno finansijskim tržištima.

\section{Zaključak}

Kada su u pitanju poslovni modeli, različiti pokazatelji nam govore da nisu sve banke spremne da menjaju svoje poslovne modele i to usled straha od samih promena, ili usled nemogućnosti da shvate značaj digitalizacije i pretnju koju tradicionalnim bankama prave savremene banke i druge finansijske institucije kao direktni konkurenti, ali isto tako i oni koji su indirektni konkurenti tradicionalnim bankama, a već su digitalizovani.

Stoga banke moraju da transformišu svoje poslovne modele, da promene svoje osnovne i sporedne procese, ali i da zamene sve one koji nisu spremni na ovakve promene. Poslovni modeli se moraju menjati zajedno sa promenom organizacione kulture takođe, a u njihovoj izmeni moraju učestvovati svi.

Ne može nosilac inovacije npr. biti tim za inovacije, izolovan od ostatka banke, već 
For the above mentioned reasons, companies strive to develop new ways of data processing primarily by using new technologies.

The Big Data concept has the following characteristics (Bholat, 2015):

- These data are large in volume since they are often collected on a granular basis (clientby-client, service-by-service, etc.);

- The data are characterized by high speed, bearing in mind their frequent collection, processing, analysis, update and renewal;

- The data differ in quality which further complicates their processing, but can be highly valuable for analysis due to their various types.

The Big Data concept has been gaining importance in the recent years since the companies that applied it in their management have enjoyed considerable benefits from the high volume of data and advanced technologies for their analysis. What should be pointed out is the time frame in which a company should expect to gain benefits from the Big Data concept implementation, since the results cannot be visible instantly, but after a certain period of time, due to the fact that every company needs to make certain preparations for this implementation (Bughin, 2016).

The banking business is a highly independent sector of the economy in the last few years which has become apparent during the last economic crisis. The Big Data concept can be of great value to the banking business if used in an adequate way. It is believed that the Big Data concept is the future of management of every entity in the financial market, including banks.

\section{Digitalization}

Digitalization is a process that has raised a lot of interest in the professional circles in the past few years. Employing new technologies in the management of any company is not a novelty but the fact that they could be used to fully automatize and digitalize business advancement attracts a lot of attention on the part of companies. In recent times, digitalization has increasingly been associated with the banking industry, since some instances have shown that it could have a significant effect on these institutions' business results. Forest and Rose (2015) point out that digitalization is a trend that has emerged as a reaction to three major factors:

- Customer experience - The aspiration to achieve a higher degree of buyers' satisfaction accelerated the process of digitalization. Buyers decide what they would buy or consume based on how well the companies satisfy their needs;

- Technology push - The development of digital infrastructure has enabled millions of users around the globe to access the technology which could significantly facilitate their everyday activities;

- Economic benefits - Digitalization stimulates economic development, job creation, cost reduction, revenue increase, etc. The information processing has been improved and processing time significantly reduced.

In order to profit from digitalization banks must develop an efficient strategy that should enable an effective digitalization of the entire business. (Ristić, Anđelić, Ilić, 2017)

Digitalization of the banking sector is the ideal towards which the banks in the developing countries are striving. As for the developed countries, digitalization is not the future of banking, but the present issue that dictates the survival of these banks in the highly competitive banking and financial markets.

\section{Conclusion}

When it comes to business models, various indicators show that banks are not ready to change them due to the fear of the change itself or due to their inability to realize the importance of digitalization or the threat posed by modern banks and other financial institutions which had already implemented digitalization and which are either their direct or indirect competitors.

This is why banks must transform their business models, including their core and other processes, at the same time replacing those that are not ready for such changes. Along with the business model changes, the changes in organizational culture must occur, with all the members participating in the change.

Furthermore, it is impossible to make a change if the innovation team, for example, is isolated from the rest of the bank. Instead, all the representatives of the important banking 
u inovacije moraju biti uključeni i drugi predstavnici važnih procesa u banci. Na kraju $\mathrm{u}$ inovaciju moraju biti uključeni upravo i oni koji donose odluke, baš zato što je potrebno bolje da razumeju šta se inovira i zašto, kao koje su prednosti i nedostaci istog. Na kraju, kada se banci čini da je odluka doneta, potrebno je tehnikom "đavoljeg advokata" upravo još jednom je preispitati, ali opet imajući pojam o vremenu. Što više odlažemo donošenje važnih odluka, kao što je odluka o izmeni poslovnog modela, uvođenju digitalizacije u poslovanje i slično, sve smo više u gubitku, odnosno direktna i potencijalna konkurencija nam sve više i upornije odmiču, do jedne tačke, kada ih je nemoguće ponovo sustići.

\section{Literatura / References}

1. Aranha, E. Prado Garcia, N. Correa, G. Open Innovation and Business Model: A Brazilian Company Case Study, Journal of Technology Management \& Innovation, Vol. 10, No. 4 (2015), p. 91-92

2. Bughin, J. Big Data: Getting A Better Read On Performance, McKinsey Quarterly, Vol. 3, No. 1 (2016)

3. Burke, A. Van Stel, R. Thurik, Blue Ocean versus Competitive Strategy: Theory and Evidence, Erasmus Research Institute of Management (2009), p. 3

4. Cheng, C. Huizingh E, When Is Open Innovation Beneficial? The Role of Strategic Orientation, Journal of Product Innovation Management, Vol. 31, No. 6, (2014), p. 1235

5. Forest, H. Rose, D. Digitalisation and the Future of Commercial Banking, Deutsche Bank (2015) - available on: http://www. cib.db.com/docs_new/Digitalisation_and_ the_Future_of_Commercial_Banking.pdf, 6//2017

6. Foroughi, N. A. Buang, Z. C. Senik, R. S. Hajmirsadeghi, M. M. Bagheri, The Role of Open Service Innovation in Enhancing Business Performance: The Moderating Effects of Competitive Intensity, Current Science, Vol. 109, No. 4 (2015), pp. 691 
processes must be included. Finally, the people who make all the decisions must be included in the process of innovation in order to understand the innovation, its purpose, advantages and disadvantages. When it finally seems that the decision has been made, it is necessary to use the devil's advocate technique to reassess it while keeping track of the time. The more we delay important decisions such as those concerning a change of the business model or digitalization, the more we are at a loss, as the direct and indirect competitors keep advancing up to the point where it is impossible to catch up with them.

7. Kim C, Mauborgne, R. Blue Ocean Strategy: From Theory to Practice, California Management Review, Vol. 47, No. 3 (2005), p. 106

8. Lindič, J. Bavdaž, M. Kovacič H. Higher Growth through the Blue Ocean Strategy: Implications for Economic Policy, Research Policy, Vol. 41 (2012), pp. 928-929

9. Mergaerts, F. Vander Vennet, R. Business Models and Bank Performance: A LongTerm Perspective, Journal of Financial Stability, Vol. 22 (2016), pp. 57

10. Roengpitya, R. Tarashev, N. Tsatsaronis, K. Bank Business Models, BIS Quarterly Review (2014), p. 55

11. Vega-Jurado, J. Juliao-Esparragoza, D. Paternina-Arboleda, C. Velez M, Integrating Technology, Management and Marketing Innovation through Open Innovation Models, Journal of Technology Management $\mathcal{E}$ Innovation, Vol. 10, No. 4 (2015), pp. 89

12. Ristić, B Anđelić S, Ilić M, Digitalization and Technological Innovations in the Banking Sector as the Imperative of the Survival of Commercial Banks, Proceedings of the XXII International Scientific Symposium, SM 2017, Subotica, 2017 